\title{
GIS Application for Health Facility Coverage Mapping in Temanggung Regency, Central Java Province
}

\author{
Arga Geofana ${ }^{1^{*}}$ \\ ${ }^{1}$ Geospatial Information Agency, Jalan Raya Bogor KM. 46, Cibinong 16911, Indonesia; \\ ${ }^{*}$ Corresponding author. $e$-mail: arga.geofana@big.go.id \\ (Diterima: 8 Januari 2021; Disetujui: 10 Mei 2021)
}

\begin{abstract}
Adequate health facilities have become one of the interesting issues to be discussed since this pandemic situation. Availability and accessibility of health facilities are the vital aspects that should be accomplished by both local and central government. Nevertheless, some population especially those living in rural areas have some difficulties in reaching these facilities due to the inequality condition within regions. This study aims to analyze the coverage of health facilities in Temanggung Regency, Central Java province and cluster its subdistricts according to their condition in accessing these facilities. The analysis is limited to public health facility (PUSKESMAS) and hospital levels. Both statistical and spatial data were processed using the GIS network analysis approach in producing the coverage number of each health facility and they were compared to the applied standard range of service and threshold. Then, a hierarchy is created using the weighted centrality index approach to represent disparities among subdistricts in Temanggung Regency regarding the availability and its coverage to health facilities. The results show that there is an inequality condition on health facilities coverage between central and peripheral areas within this regency, both at the public health facility level and hospital level. Several population in several districts, mostly residing in outer areas, are not covered by both public health facility and hospital. On the other hand, people in the capital and its surrounding subdistricts have better access to these facilities. Several factors are identified in producing this inequality, such as spatial distribution of housing areas, spatial allocation of health facilities, road network, and topographic condition. The topographic condition in some uncovered areas, which is relatively hilly and has steep slope, causes limited access to the road network and less coverage of health facilities.
\end{abstract}

Keywords: Geographic Information System, health facilities, inequality

\section{INTRODUCTION}

One of the vital topics in rural development and regional planning subjects is related to imbalanced development which mostly occurs in developing nations (Alonso, 1968; Friedmann \& Alonso, 1976). This inequality condition covers so many sectors such as health, socio-economic, and education. In terms of the health sector, there is a gap among population for those living in rural areas compared to urban dwellers. People in rural areas are commonly more difficult in accessing health facilities due to inadequate health amenities and their supporting infrastructures. Besides, a city hierarchy also plays an important role in causing this disparity of health services within urban-rural regions (Zeng et al., 2015). Therefore, some interventions through public policies should be created by the government regarding this inequality condition (Bull et al., 2001; Jensen \& Royeen, 2002; Nelson \& Gingerich, 2010). Furthermore, these interventions have to consider some aspects of 
health facilities, such as their ideal location, and ideal capacity. This can be calculated through spatial interaction and supply-demand analysis (Luo et al., 2017). By doing a suitable intervention, the health utilization gap among urban-rural regions could be minimized (Yin, 2018).

In terms of rural and regional development, a health service within a region is a vital role since it is a basic necessity for each person. In several studies, the existence of qualified health services is the key to the success of a district or municipality in getting good performance scores and it is one of the used indicators in calculating the disparities level among regions (Fauzi et al., 2019, Soares et al., 2017). Therefore, in achieving this goal, the local government needs to build an adequate plan to reduce the disparities in the health sector by analyzing the gap and develop more health facilities. Nevertheless, without an appropriate gap analysis in the planning process, this approach could not work optimally (Liew \& Gardner, 2014). On the other hand, some problems related to the bureaucracy and economic aspect could harmful vulnerable people in accessing the health facilities. In terms of the administrative aspect, the inconsistency of policies within a district could trigger more resistance to health facilities in serving adequate service (Heywood \& Harahap, 2009). Besides, some hospitals are shifting into more profitoriented actors rather than public authorities which are more influenced by the economic condition (Kristiansen \& Santoso, 2006).

Location becomes one of the vital aspects in performing an excellent service and achieving people satisfaction especially for the health sector since health facilities location influences how people reach these basic services (Liew \& Brooks, 2016). This becomes one of the biggest challenges in Temanggung Regency which most of its areas are hilly with a range of height is around 500-3000 meters above sea level. This topographical character complicates the population in utilizing these facilities and it is a key factor affecting the performance level of these amenities (Irawan \& Ainy, 2018).
Furthermore, another factor such as the spatial distribution of population influences the health facilities location, and this condition narrows the inequality condition (Kompil et al., 2019). This factor differentiates the distance for each population in obtaining a health service. As an impact, this unideal condition leads to ineffective governance and resists the creation of sustainability within this district. Hence, an adequate spatial plan optimizing all the possible resources has to be applied to prevent these shocks (Bibri \& Krogstie, 2017; Bourdic et al., 2012).

There are some ideal parameters related to the location term that should be required by the amenities namely threshold and range of service (Christaller, 1933). The ideal location must comply with the minimum standards of these parameters. Even though this approach called central place theory refers to economic activities, this could be adopted and applied to the public services sector. It is stated that the ideal service would be easier to achieve when the facility location is closer to the population. Besides, Daldjoeni (1992) explains that a central place does not only serve people within its region but also provides services to its hinterland communities. Furthermore, according to this theory, applying of threshold and range of service is needed also to ensure that health facilities are well accessible and having adequate availability especially in the current pandemic situation due to the COVID-19 virus.

In completing the analysis, GIS appears as a tool to ease planner's necessities. Several GIS applications in the planning and development sectors already improve the quality of the decision-making process (ZwirowiczRutkowska \& Michalik, 2016). The most utilization of GIS refers to the environmental sector. Most of the planners use this approach to deal with environmental issues. Classifying land cover in detecting the environmental impact of land-use changes becomes the vital function of this approach (Paez \& Scott, 2004; Hadeel \& Jabbar, 2011). Nevertheless, GIS could be used also in the health sector. For instance, this method was already used to identify the supply 
and demand distribution of hospital services (Murad, 2007). In this research, GIS is utilized to find out the disparities of health facilities by calculating the threshold and range of service parameters.

This research aims to calculate the disparities occurred by the population in each subdistrict within Temanggung Regency in accessing hospital and public health center (PUSKESMAS) services. In achieving this goal, the quantitative approach using GIS network analysis was applied. By using this approach, these health facilities will be evaluated whether they already cover all of the population or not by comparing their coverage to the minimum applied standards (range of service and threshold) (Hazrin et al., 2014; Munoz \& Källestål, 2012). Besides, this method could calculate availability and accessibility gaps for health facilities which can be used as a basis by the local government to optimize their health services. In the end, a hierarchy is created to represent the disparities among subdistricts of health facilities coverage within Temanggung Regency.

\section{METHODOLOGY}

\section{Standard Range of Service and Threshold in Indonesian Health Services}

There are some standards and policies in Indonesia related to the spatial allocation of health facilities in Indonesia. These policies rule on how and where the health facilities should be constructed. Generally, in these policies and standards, the applied rules covering the range of service and threshold for both hospital and public health center are accommodated as a basis of the disparities calculation.

In terms of a public health center, the Indonesian Standard Document (SNI) No. 031733-2004 related to the procedure of housing environmental planning states that a public health center must cover a minimum of 120,000 people with the maximum range of service is within a radius of three kilometers. In addition, this facility has to be located in the center of the region and it can be accessed by public transportation. Furthermore, another policy coming from the Health Minister Decree No. $75 / 2014$ on the general term of public health center explains that this facility has to be constructed in each subdistrict in Indonesia. In the case of several aspects such as accessibility and capacity, it is possible to build another public health center to accommodate people's health necessities.

Regarding the hospital level, the threshold of its services is adopted from a policy released by the Minister of Settlement and Regional Infrastructure Decree No. 534/KPTS/M/2001 on the guidelines for determining minimum standard service in spatial planning, housing, and general work. This policy states that a threshold for hospital services is 240,000 population. Nevertheless, some policies related to the hospital range of services were not found. Thus, a literature review related to this term is adopted. In one of the studies, it is stated that an ideal coverage of hospital services is 10 kilometers (Roberts et al., 2014). This range of service is derived from the calculation of the origins which the majority of emergency cases are coming from.

Table 1. Range of service and population threshold of health facilities in Indonesia

Types of Health Facilities

\begin{tabular}{cccl}
\hline Public health centre (PUSKESMAS) & 120,000 & $3 \mathrm{~km}$ & $\begin{array}{l}\text { 1. Centre of region } \\
\begin{array}{c}\text { 2. Accessible for } \\
\text { the public } \\
\text { transportation }\end{array}\end{array}$ \\
\hline Hospital & 240,000 & $10 \mathrm{~km}$ & \\
\hline
\end{tabular}

Sources: SNI (2004); Kemenkes (2014); KemenPU (2001); Roberts et al (2014). 


\section{Data Collection}

Generally, in calculating this disparity calculation, both statistical and spatial data are required. Regarding the statistical data, the total population and number of health facilities in Temanggung Regency are obtained from Badan Pusat Statistik (BPS). First of all, the number of health facilities in each subdistrict was checked to ensure the availability of this facility. Then, population data are needed to define whether each health facility in a particular subdistrict reaches the minimum threshold which is already set or not. Table 2 represents the statistical data covering population data and the number of health facilities in Temanggung Regency.

Table 2. Demography and availability of health facilities data in Temanggung Regency

\begin{tabular}{|c|c|c|c|}
\hline \multirow[b]{2}{*}{ Subdistricts } & \multirow[b]{2}{*}{ Total Population in 2018} & \multicolumn{2}{|c|}{ Types of Health Facilities } \\
\hline & & Hospital & $\begin{array}{c}\text { Public } \\
\text { HealthCenter } \\
\text { (PUSKESMAS) }\end{array}$ \\
\hline Bansari & 22,469 & & 1 \\
\hline Bejen & 20,198 & & 1 \\
\hline Bulu & 48,484 & 1 & 1 \\
\hline Candiroto & 30,868 & & 1 \\
\hline Gemawang & 33,035 & & 1 \\
\hline Jumo & 29,311 & & 1 \\
\hline Kaloran & 41,235 & & 2 \\
\hline Kandangan & 49,919 & & 1 \\
\hline Kedu & 58,908 & & 1 \\
\hline Kledung & 24,789 & & 1 \\
\hline Kranggan & 48,159 & & 2 \\
\hline Ngadirejo & 53,563 & & 2 \\
\hline Parakan & 52,768 & 1 & 2 \\
\hline Pringsurat & 50,983 & & 2 \\
\hline Selopampang & 18,944 & & 1 \\
\hline Temanggung & 83,094 & 2 & 2 \\
\hline Tembarak & 30,126 & & 1 \\
\hline Tlogomulyo & 23,439 & & 1 \\
\hline Tretep & 20,218 & & 1 \\
\hline Wonoboyo & 25,084 & & 1 \\
\hline Total & 765,594 & 4 & 26 \\
\hline
\end{tabular}

Source: BPS (2019). 
In terms of spatial data in Temanggung Regency, most of the data were obtained from the Indonesian Topographic Map on the scale of 1:25,000 produced by Badan Informasi Geospasial (BIG). Some layers such as transportation, housing, health infrastructure, and administration boundary were obtained from this topographic map. Nevertheless, most of the spatial data were out of date since they were produced in the year 2000 using the aerial photo of 1994. This condition could result in some housing areas being excluded from the analysis caused by the rapid land-use change phenomenon. Therefore, some additional spatial data collected from other sources such as Open Street Map (OSM) and Google Earth are needed to improve the input data. The additional housing areas which are located outside of existing housing areas from the topographic map were extracted from the OSM. Whereas the coordinate points of health facilities were derived from Google Earth to ensure all of the health facilities are included in the analysis.

\section{Analysis Method}

In defining the coverage of each health facility, some analyses using a GIS-based approach were done. Network analysis was the main spatial tool to define the coverage of each health facility. By doing this analysis, the calculation of service area is calculated by considering the existing road network within the Temanggung Regency. Other spatial analyses such as overlay, topology, and feature geometry calculation were applied in obtaining the detailed information of coverage and accessibility of each health facility. Besides, these analyses were used to identify the spatial distribution of population and the spatial structure of each subdistrict. This information is required to analyze some factors triggering these disparities.

The next step is to identify several factors causing inequality of the health facilities coverage in Temanggung Regency based on the coverage calculation of these facilities. In carrying out this process, study literature was done as a first step in identifying some factors causing the inequality condition. After obtaining these several factors producing disparities, each subdistrict is analyzed based on the identified factors and the results of health facilities coverage. Then, conducting some comparisons between subdistricts that have different conditions is needed to analyze the disparities.

A hierarchy was also created using the scalogram method and the weighted centrality index to serve a better perspective in showing the disparities of each subdistrict. In this analysis, each subdistrict was marked according to the availability of health facilities and the coverage of these facilities. By doing this hierarchy analysis, it can be seen how the subdistricts included in the higher hierarchy could have more advantages compared to others that are categorized to the lower hierarchy.

\section{RESULTS AND DISCUSSION}

\section{Inequality Condition of Health Service Coverage in Temanggung Regency}

Before calculating the disparities among subdistricts, it is necessary to identify the spatial distribution of population and health facilities in each subdistrict. In terms of the population distribution represented by figure 1, Temanggung Subdistrict as capital had the largest population categorized over 70,000 population. Some surrounding subdistricts from the capital area were classified into areas with the number of populations within 50,000 to 70,000 people. The rest of them which are mostly located in the outer area of this regency had under 50,000 total population.

In terms of the spatial distribution of health facilities, figure 1 shows that all of the hospitals within this regency are operated in the capital subdistrict and its neighboring subdistricts. All of the hospitals are concentrated in these subdistricts and these hospitals are located close to each other. Moreover, the total population within these subdistricts is higher than others. As a result, this condition triggers the inequality caused by the uneven distribution of hospital services. Figure 1 shows that people residing in the southern part of this regency 
might have better access to the hospital services compared to population living in the northern part.

In terms of the public health center, all of the subdistricts are already occupied by this facility. In addition, some subdistricts already have an additional public health center. However, it is necessary to look further at whether the addition of this facility could reduce or even eliminate the disparities within the subdistrict or not.

Regarding the population threshold aspect, both the hospital and public health center in Temanggung Regency already reach the ideal condition by complying with this standard. These facilities could serve the population ideally since the population threshold is completed. There would be no overcapacity condition in serving the population in the normal condition. For instance, the public health center using the 120,000 populations threshold fulfills the threshold clearly since there is no subdistrict having the population as large as the threshold and this facility is evenly distributed into each subdistrict. Moreover, each of them could provide its services to people coming from the surrounding subdistricts.

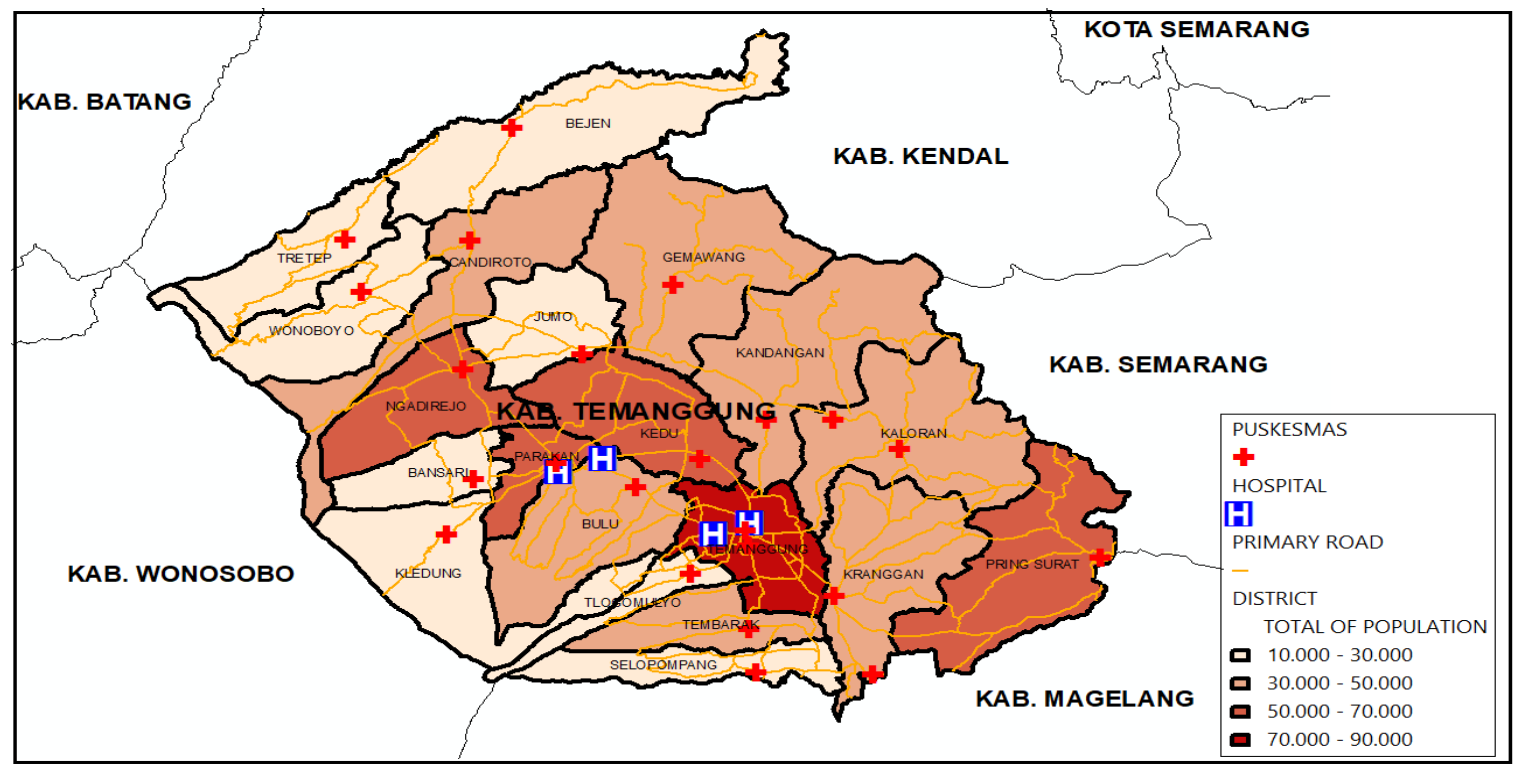

Figure 1. Spatial distribution of health facilities compared to the total population

Meanwhile, the opposite condition occurred for the range of service aspect. When the population threshold was fulfilled, not all residential areas are covered by either hospital or public health service. In terms of public health service, based on the spatial analysis represented by figure 2 , the total area covered by this health facility was counted as more than 47 percent or around 4,748 hectares. More than half of housing areas do not obtain an ideal service of public health center. It means that people coming from these areas have to travel more than three kilometers in reaching this facility.

If it is looked into more detail, the spatial distribution of these uncovered areas is mostly located in the outer area of Temanggung Regency, and these locations have a far distance to the capital subdistrict as the growth center of this region. On the contrary, most of the housing areas in the capital and its surrounding subdistrict such as Parakan and Tlogomulyo are already covered by the public health center services even though not fully covered. Moreover, people in these areas have more benefits because they are covered by more than one public health facility. So that, they have few options to reach this health facility in an ideal range. In addition, total areas that have overlapping coverage of public health facilities 
were counted as 888 hectares or around 9 percent of Temanggung Regency's total area.

Even though not all subdistricts located near the capital region are covered by the public health facility in a good number (Table 3), but still they have better coverage compared to the outer subdistricts. This condition produces inequality among subdistricts since some areas are covered by an overlapping coverage of this facility while others do not have any. Figure 2 represents the coverage areas of the public health center in Temanggung Regency.

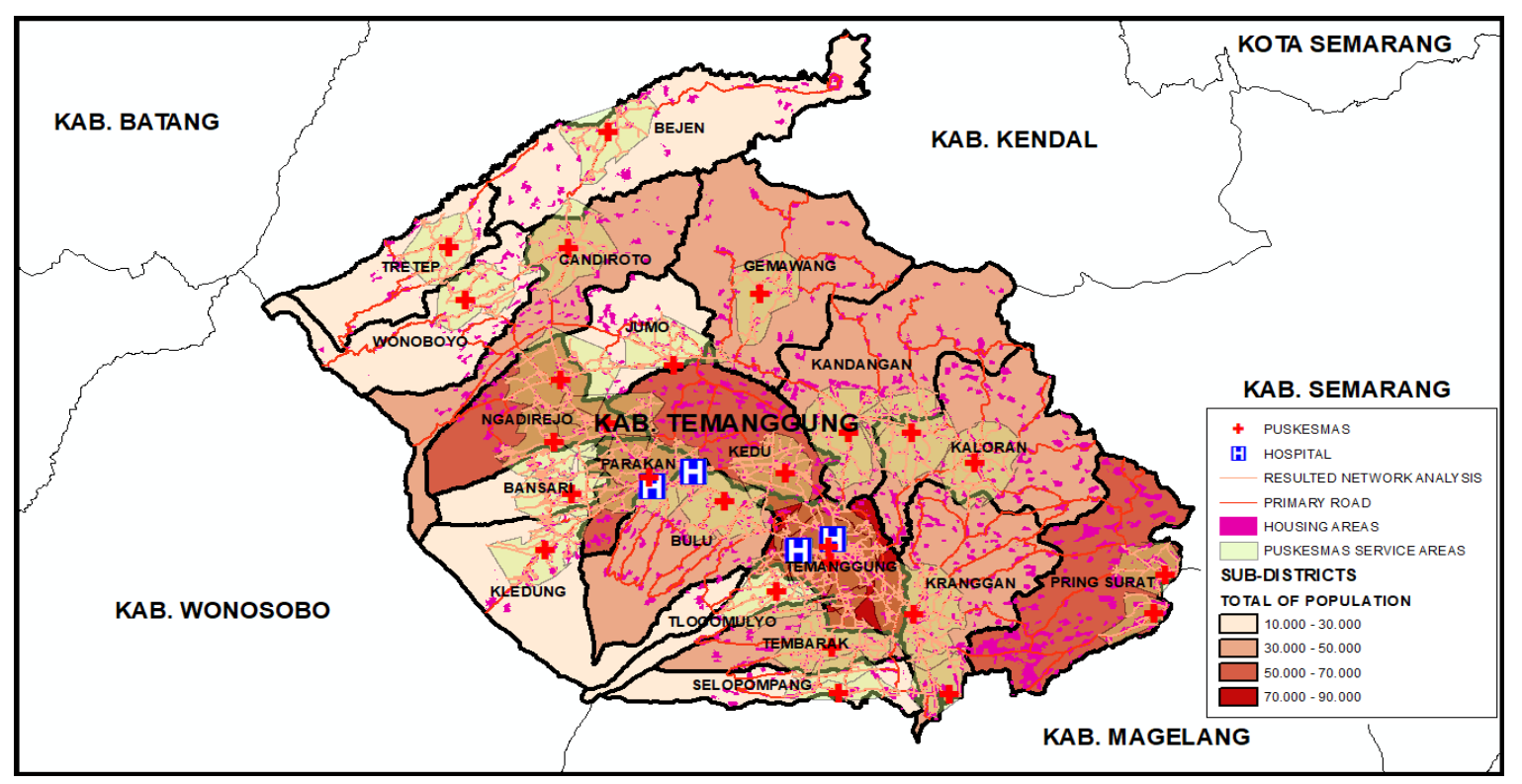

Figure 2. Public health centres coverage areas in Temanggung Regency

A similar condition occurred also at the hospital level. Even though the population threshold was completed by all of the hospitals, the range of services needs to be improved. There are four hospitals within this regency meaning that these amenities could comply with the total population in Temanggung Regency. Furthermore, these hospitals could serve more people coming from the surrounding regencies.

Regarding the hospital's range of services, Figure 3 represents how the coverage of all hospitals in Temanggung Regency. According to this analysis, some areas having more advantages instead of others indicates that the disparities occurred among subdistricts. Some peripheral regions such as Tretep, Bejen, and Wonoboyo Subdistricts are not fully covered by the hospital services. On the other hand, the capital region has much better services of this facility, and people in this region are served by more than a hospital in an ideal distance. Further analysis shows the detail of these disparities by analyzing the number of residential areas affected by this condition. 


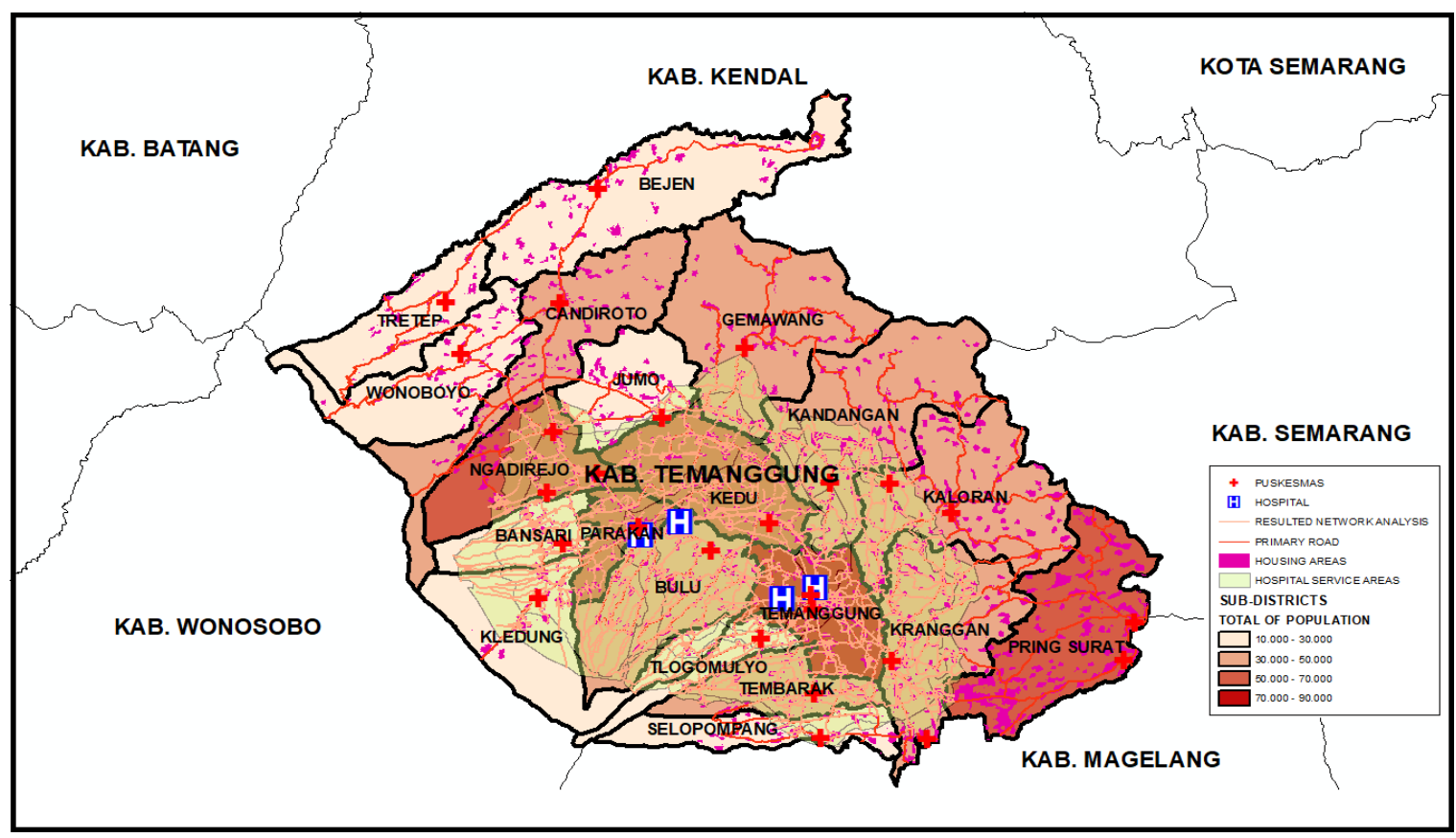

Figure 3. Hospitals coverage areas in Temanggung Regency

According to the calculation of hospital coverage, more than 53 percent of the housing area in Temanggung Regency area was covered by the ideal range of hospital services. These areas are identified as having a larger population than the peripheral areas which are not reached by this facility. This condition also indicates that there was an imbalance development among the subdistricts. Then, the number of overlapping areas having more than one hospital service in ideal distance reaches 44 percent of the total Temanggung Regency area. It indicates that the spatial allocation of the hospitals is not evenly distributed. The location of all hospitals is not well distributed to cover all the housing areas in Temanggung Regency. Table 3 represents the detailed number of health facilities coverage.

Table 3. Detail results of health facilities coverage

\begin{tabular}{lcccccc}
\hline Sub-districts & $\begin{array}{c}\text { Distance } \\
\text { from the } \\
\text { capital } \\
\text { subdistrict } \\
\text { (Km) }\end{array}$ & $\begin{array}{c}\text { Total of } \\
\text { housing } \\
\text { areas } \\
\text { (Hectares) }\end{array}$ & $\begin{array}{c}\text { Percentage } \\
\text { of housing } \\
\text { areas } \\
\text { covered by } \\
\text { a public } \\
\text { health } \\
\text { center } \\
\text { service }\end{array}$ & $\begin{array}{c}\text { Percentage } \\
\text { of housing } \\
\text { areas } \\
\text { covered by } \\
\text { more than } \\
\text { one public } \\
\text { health } \\
\text { center } \\
\text { Services }\end{array}$ & $\begin{array}{c}\text { Percentage } \\
\text { of housing } \\
\text { areas } \\
\text { a hospital } \\
\text { service }\end{array}$ & $\begin{array}{c}\text { Percentage } \\
\text { oreasing } \\
\text { covered by } \\
\text { more than } \\
\text { one } \\
\text { hospital } \\
\text { services }\end{array}$ \\
\hline Temanggung & 0 & 851.7 & $92.27 \%$ & $62.64 \%$ & $100.00 \%$ & $100.00 \%$ \\
\hline Kranggan & 4 & 797.9 & $44.30 \%$ & $2.12 \%$ & $70.76 \%$ & $48.98 \%$ \\
\hline Tlogomulyo & 5 & 122.8 & $77.93 \%$ & $13.76 \%$ & $100.08 \%$ & $99.19 \%$ \\
\hline Bulu & 6 & 553.7 & $41.45 \%$ & $5.69 \%$ & $100.00 \%$ & $100.00 \%$ \\
\hline Kedu & 6 & 688.2 & $31.55 \%$ & $0.04 \%$ & $100.00 \%$ & $100.00 \%$ \\
\hline Kandangan & 8 & 701.4 & $61.39 \%$ & $3.45 \%$ & $60.44 \%$ & $33.95 \%$ \\
\hline Tembarak & 8 & 354.2 & $62.65 \%$ & $2.71 \%$ & $91.42 \%$ & $87.78 \%$ \\
\hline
\end{tabular}




\begin{tabular}{|c|c|c|c|c|c|c|}
\hline Sub-districts & $\begin{array}{l}\text { Distance } \\
\text { from the } \\
\text { capital } \\
\text { subdistrict } \\
\text { (Km) }\end{array}$ & $\begin{array}{c}\text { Total of } \\
\text { housing } \\
\text { areas } \\
\text { (Hectares) }\end{array}$ & $\begin{array}{c}\text { Percentage } \\
\text { of housing } \\
\text { areas } \\
\text { covered by } \\
\text { a public } \\
\text { health } \\
\text { center } \\
\text { service }\end{array}$ & $\begin{array}{c}\text { Percentage } \\
\text { of housing } \\
\text { areas } \\
\text { covered by } \\
\text { more than } \\
\text { one public } \\
\text { health } \\
\text { center } \\
\text { Services }\end{array}$ & $\begin{array}{c}\text { Percentage } \\
\text { of housing } \\
\text { areas } \\
\text { covered by } \\
\text { a hospital } \\
\text { service }\end{array}$ & $\begin{array}{c}\text { Percentage } \\
\text { of housing } \\
\text { areas } \\
\text { covered by } \\
\text { more than } \\
\text { one } \\
\text { hospital } \\
\text { services }\end{array}$ \\
\hline Parakan & 12 & 335.8 & $83.95 \%$ & $20.82 \%$ & $100.00 \%$ & $100.00 \%$ \\
\hline Selopampang & 14 & 248.8 & $57.76 \%$ & $12.18 \%$ & $44.69 \%$ & $25.76 \%$ \\
\hline Kaloran & 15 & 823.4 & $35.52 \%$ & $0.41 \%$ & $24.68 \%$ & $17.08 \%$ \\
\hline Pringsurat & 16 & 1266.9 & $20.38 \%$ & $0.00 \%$ & $1.10 \%$ & $0.00 \%$ \\
\hline Bansari & 18 & 262.9 & $96.58 \%$ & $12.93 \%$ & $100.00 \%$ & $100.00 \%$ \\
\hline Ngadirejo & 19 & 536.5 & $76.66 \%$ & $21.66 \%$ & $73.81 \%$ & $45.85 \%$ \\
\hline Gemawang & 20 & 463.4 & $29.11 \%$ & $0.00 \%$ & $25.14 \%$ & $13.66 \%$ \\
\hline Kledung & 22 & 285.4 & $64.19 \%$ & $0.40 \%$ & $87.39 \%$ & $66.61 \%$ \\
\hline Jumo & 24 & 324.1 & $53.16 \%$ & $0.00 \%$ & $28.79 \%$ & $4.88 \%$ \\
\hline Candiroto & 28 & 398.1 & $36.42 \%$ & $0.00 \%$ & $0.00 \%$ & $0.00 \%$ \\
\hline Wonoboyo & 33 & 279.8 & $36.85 \%$ & $0.00 \%$ & $0.00 \%$ & $0.00 \%$ \\
\hline Bejen & 34 & 452.5 & $29.57 \%$ & $0.00 \%$ & $0.00 \%$ & $0.00 \%$ \\
\hline Tretep & 40 & 197.7 & $21.29 \%$ & $0.00 \%$ & $0.00 \%$ & $0.00 \%$ \\
\hline
\end{tabular}

\section{Some Factors influencing the inequality coverage of health service}

Table 3 was sorted based on the subdistrict distance to the capital subdistrict. Based on the results, there are no subdistricts that are fully covered by the services of the public health center. On the other hand, there are several subdistricts whose housing areas are fully covered by the hospital services. According to this condition, at least there are four main factors in covering large housing areas for certain subdistrict.

First of all, the agglomeration of residential areas in Bansari Subdistrict has become the key factor in serving the health service equally to the population since they only have a public health center. It indicates that the spatial distribution of the population plays an important role for population in obtaining a better health service (Kompil et al., 2019). The more scattered residential areas within a region, the more public services would become more ineffective and it leads to the inequality condition (Putra, 2014). Because of their scattered housing distribution, some subdistricts such as Pringsurat, Candiroto, and Gumawang only have small coverage of public health center services.

Next, an appropriate spatial allocation is the main factor to optimize the coverage of health facilities (Polo et al., 2015). For instance, regarding the hospital coverage areas, the gap of services occurring in certain areas is linear to the distance from it to the capital subdistrict. It means that people residing in the capital region have more advantages in accessing the hospital services instead of people in outer areas. The 
worst thing related to this condition is that three subdistricts are not completely covered by hospital services within an ideal distance. These subdistricts (Wonoboyo, Bejen, and Tretep) have the furthest distance to the capital region and it makes no hospital service coverage within these subdistricts. Another instance could be seen in the Kedu subdistrict. The unideal placement of public health centers causing a small coverage percentage within this subdistrict. Most of the housing areas in the western and northern parts of this subdistrict were not covered by the public health center services. Figure 4 shows the uneven coverage of this facility.

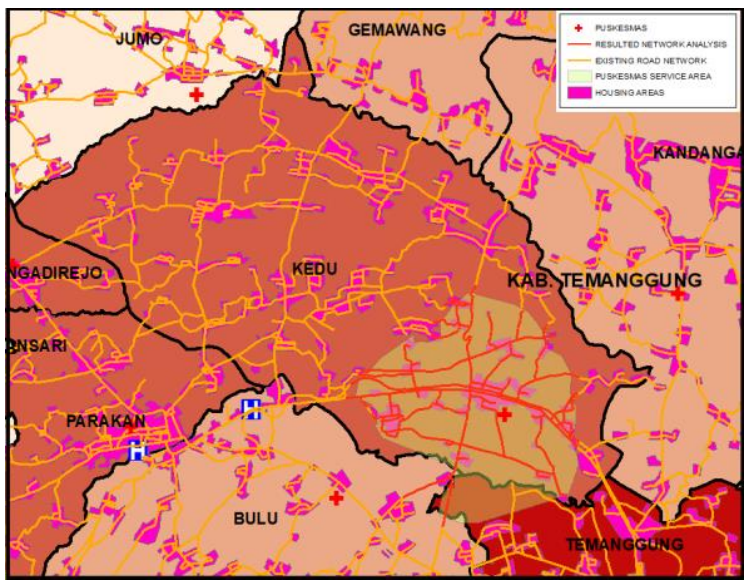

Figure 4. Spatial allocation effect to the health facility coverage

To handle this situation, the local government has created some improvements in solving this coverage gap by creating more public health facilities in several subdistricts such as Temanggung, Ngadirejo, Pringsurat, Kranggan, Parakan, and Kaloran. Nevertheless, the analysis indicates that some additional health facilities were not placed in an ideal location. For instance, the additional public health center in Temanggung and Ngadirejo Subdistricts could not cover whole housing areas within these subdistricts. There is a big overlap of coverage area among the public health centers. In this case, the additional health facility could not reach all of the housing areas since it was built near the previous health center and not near the uncovered location.

The last factor is related to the road network and the topographical condition in each subdistrict. Some subdistricts do not have adequate road networks and this condition leads to the small coverage of health facilities. This condition is influenced also by the topographic condition of each subdistrict (Dai, 2010). The topographic condition in some uncovered areas which is relatively hilly and has a steep slope causes limited access to the road network and less coverage of health facilities.

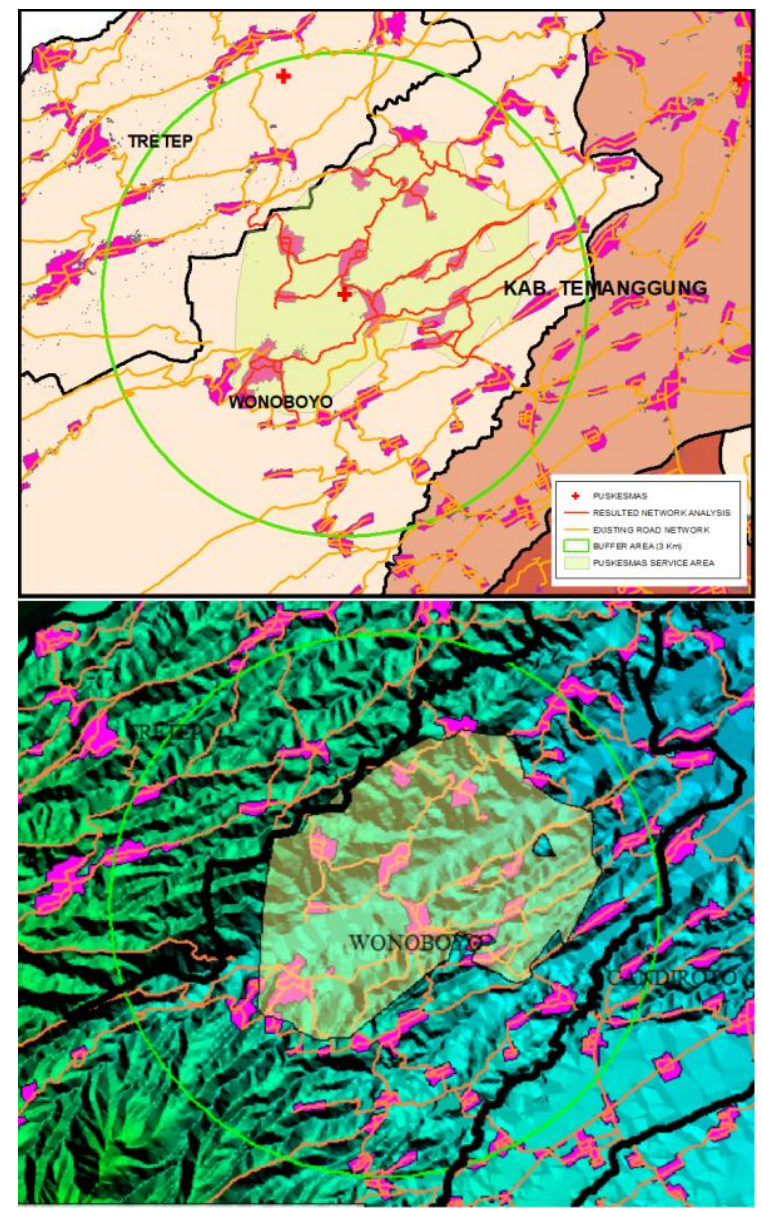

Figure 5. Road network and topographical effect to the health facility coverage

It can be seen through the example of public health center coverage in Wonoboyo Subdistrict in figure 5. The placement of this facility is already in an ideal place. However, the inadequate road network caused by the hilly condition becomes the main factor influencing the small number of this coverage. Compared to the buffer area, the resulted service area from network analysis shows a much smaller coverage area due to its road network. With a 
more proper road network, bigger areas will be covered by this health facility.

\section{The Hierarchy}

The hierarchy was created to clearly identify which areas should be prioritized for the improvement of health facilities especially for some areas having no coverage of either public health facility and hospital services. A hierarchy was created using a weighted centrality index which is normally used to determine the spatial structure of a certain region by considering all of the amenities. This technique can be used to determine the central region and its hinterland. In this case, it was created only based on the availability and coverage of the health facilities of each subdistrict in order to ease the reader in identifying the subdistrict which has lacks accessibility to health facilities.

According to the analysis, there were 5 classes representing different conditions in accessing health facilities. Table 4 represents the results of the hierarchical analysis at the subdistrict level in Temanggung Regency.

Table 4. Subdistrict's hierarchy based on the health facilities coverage

\begin{tabular}{|c|c|c|}
\hline Hierarchy & Detail of hierarchy & Subdistrict(s) \\
\hline Hierarchy 1 & $\begin{array}{l}\text { - There is a hospital within the area } \\
\text { - Fully covered by more than one hospital } \\
\text { - Partially covered by more than one public health } \\
\text { facilities }\end{array}$ & Temanggung, Parakan, Bulu \\
\hline Hierarchy 2 & $\begin{array}{l}\text { - Fully covered by more than one hospital } \\
\text { - Partially covered by more than one public health } \\
\text { facilities }\end{array}$ & Bansari, Kedu \\
\hline Hierarchy 3 & $\begin{array}{l}\text { - Fully covered by one hospital } \\
\text { - Partially covered by more than one public health } \\
\text { facilities }\end{array}$ & Tlogomulyo \\
\hline Hierarchy 4 & $\begin{array}{l}\text { - Partially covered by more than one hospital } \\
\text { - Partially covered by more than one public health } \\
\text { facilities }\end{array}$ & $\begin{array}{l}\text { Selopampang, Tembarak, } \\
\text { Ngadirejo, Kranggan, } \\
\text { Kledung, Kandangan, Kaloran }\end{array}$ \\
\hline Hierarchy 5 & $\begin{array}{l}\text { - There is no area covered by hospital services } \\
\text { - } \quad \text { Partially covered by one public health facilities } \\
\text { - } \quad \text { *Partially covered at least by one hospital service }\end{array}$ & $\begin{array}{l}\text { *Gemawang, *Jumo, } \\
\text { *Pringsurat, Bejen, } \\
\text { Wonoboyo, Tretep, Candiroto }\end{array}$ \\
\hline
\end{tabular}

The hierarchy shows the disparities among health facilities coverage within the region. There are just a few subdistricts having adequate facilities for their population such as Temanggung, Bulu, and Parakan. These subdistricts are located mostly in the center of the regency or the surrounding of the capital subdistrict. On the other hand, other subdistricts located in the outer area of Temanggung Regency have less accessibility to these health facilities. Figure 4 represents how this disparity occurs spatially. 


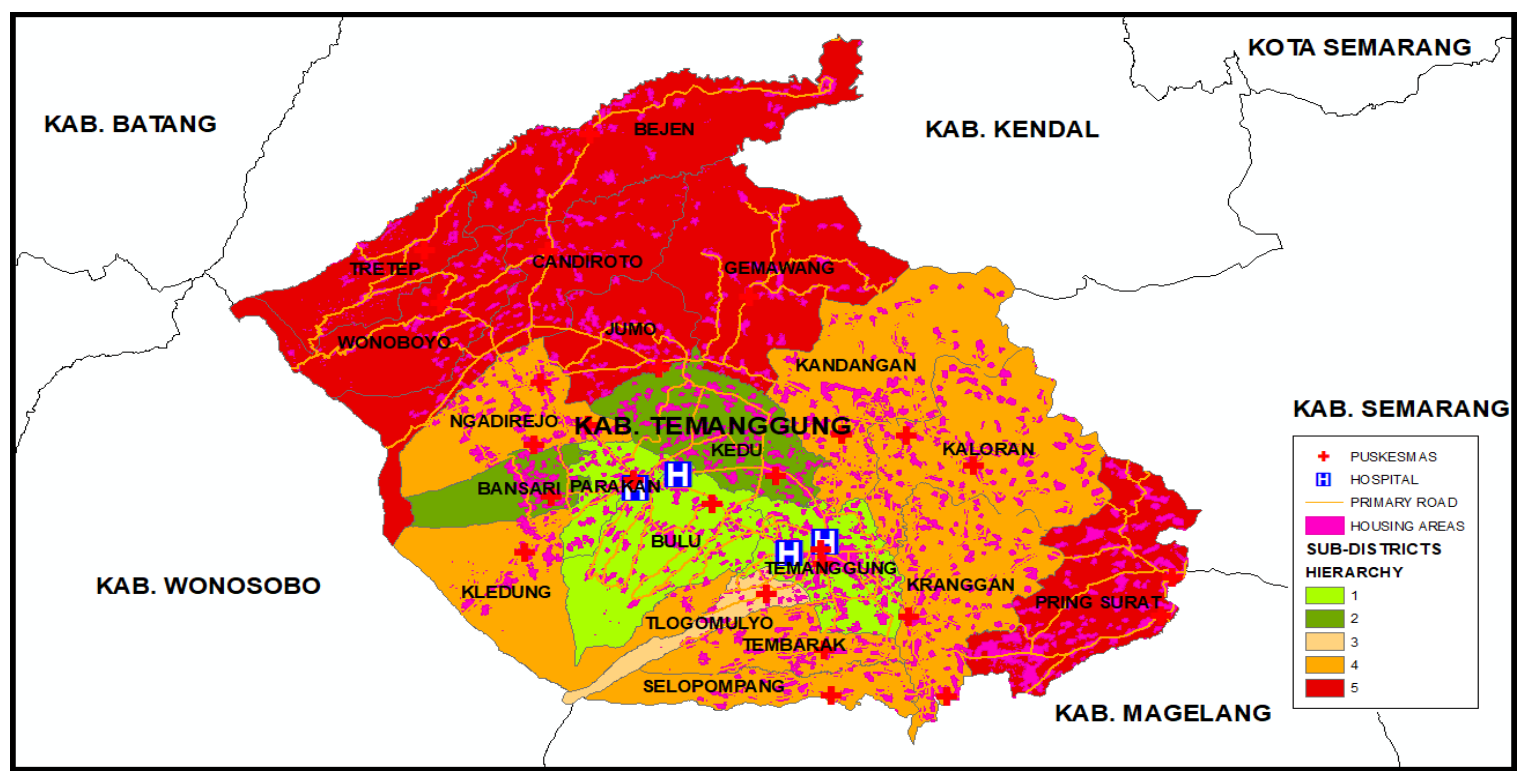

Figure 6. Spatial distribution of health facilities compared to the subdistrict's hierarchy

\section{CONCLUSIONS}

1. The disparities of health facilities occur among subdistricts in Temanggung Regency. It is indicated from the inequality condition between the capital and peripheral areas. Some residential areas in the outer subdistricts have less coverage of both the public health center and hospital services compared to the capital regions. Moreover, some areas are having no coverage at all of these facilities. On the other hand, people in Temanggung Subdistrict and its surrounding areas have more benefits since they are served by several health facilities on both levels. These disparities are represented by the hierarchy. The subdistricts classified in hierarchy 1 have more benefits instead of other hierarchies. On the other hand, some subdistricts grouped in hierarchy 5 become the most vulnerable group because of the lack of accessibility to the health facilities.

2. The relation between the disparities and the distance of an area to the capital region is linear. A closer distance to the capital region leads to better access to health facilities, vice versa. Some subdistricts located in the furthest distance to the capital region having bigger possibilities to be classified into a lower hierarchy.

3. At least four factors are influencing the coverage of health facilities in Temanggung Regency. The spatial distribution of the population becomes the key factor in both creating and reducing the disparities. An agglomerated residential area leads to the equal acceptance of health services. This coverage is influenced also by the spatial allocation of health facilities, road networks, and the topographical condition. By placing a health facility in a proper place which considering the accessibility and spatial distribution of the population, more housing areas could be covered by the health service.

\section{RECOMMENDATIONS}

1. Constructing the additional health facilities can be used as an option to reduce the inequality condition of health services. Nevertheless, it should be built in a suitable location to optimize its coverage and avoid overlapping areas among health facilities. Therefore, a proper spatial allocation analysis should be used as a basis for determining its location.

2. The spatial analysis was done using old spatial data produced a long time ago. This 
condition leads to inaccurate calculation since there must be land-use changes in several areas. Therefore, the updating of the topographic map especially for the largescale map has to be done by the authorized institution immediately. By using the updating and more accurate spatial data in the analysis, the local government could produce better policies especially for something that related to the infrastructure allocation.

\section{REFERENCES}

Alonso, W. (1968). Urban and Regional Imbalances in Economic Development Author ( $\mathrm{s}$ ): William Alonso Source: Economic Development and Cultural Change, Vol . 17, No . 1 ( Oct ., 1968 ), pp . 1-14 Published by: The University of Chicago Press Stable URL : https://www.jst. Economic Development and Cultural Change, 17(1), 1-14.

Bibri, S. E., \& Krogstie, J. (2017). Smart sustainable cities of the future: An extensive interdisciplinary literature review. Sustainable Cities and Society, 31, 183-212.

Bourdic, L., Salat, S., \& Nowacki, C. (2012). Assessing cities: A new system of cross-scale spatial indicators. Building Research and Information, 40(5), 592-605.

Bull, C. N., Krout, J. A., Rathbone-McCuan, E., \& Shreffler, M. J. (2001). Access and issues of equity in remote/rural areas. Journal of Rural Health, 17(4), 356-359.

Christaller, W. (1933). Central places in southern Germany.(Translated by Carlisle W. Baskin. Englewood Cliffs.) Prentice-Hall. New Jersey.

Dai, D. (2010). Black residential segregation, disparities in spatial access to health care facilities, and late-stage breast cancer diagnosis in metropolitan Detroit. Health and Place, 16(5), 1038-1052.

Daldjoeni, N. (1992). Geografi Baru Organisasi Keruangan Dalam Teori dan Praktek: Bandung. Penerbit PT Alumni.
Fauzi, M. R., Rustiadi, E., \& Mulatsih, S. (2019). Ketimpangan, Pola Spasial, dan Kinerja Pembangunan Wilayah di Provinsi Jawa Timur. Journal of Regional and Rural Development Planning (Jurnal Perencanaan Pembangunan Wilayah Dan PerdesaanJP2WD), 3(3), 157-171.

Friedmann, J. \& W. Alonso (eds.) (1976). Regional development planning: the progress of a decade, in Friedmann dan Alonso (eds.) Regional Development and Planning: Readings in Theory and Applications. Cambridge: MIT Press, pp. 792- 808.

Hadeel, A. S., Jabbar, M. T., \& Chen, X. (2011). Remote sensing and GIS application in the detection of environmental degradation indicators. Geo-Spatial Information Science, 14(1), 39-47.

Hazrin, H., Tahir, A., \& Fadhli, Y. (2014). Implementation of Web based GIS Application for Mapping of Health Facilities, Services and Providers in Malaysia. Global Journals Inc. (USA), 14(5), 46-50.

Heywood, P. F., \& Harahap, N. P. (2009). Human resources for health at the district level in Indonesia: The smoke and mirrors of decentralization. Human Resources for Health, 7, 1-16.

Irawan, B., \& Ainy, A. (2018). Analisis Faktor-Faktor Yang Berhubungan Dengan Pemanfaatan Pelayanan Kesehatan Pada Peserta Jaminan Kesehatan Nasional Di Wilayah Kerja Puskesmas Payakabung, Kabupaten Ogan Ilir. Jurnal Ilmu Kesehatan Masyarakat, 9(3), 189-197.

Jensen, G. M., \& Royeen, C. B. (2002). Improved rural access to care: Dimensions of best practice. Journal of Interprofessional Care, 16(2), 117-128.

Kompil, M., Jacobs-Crisioni, C., Dijkstra, L., \& Lavalle, C. (2019). Mapping accessibility to generic services in Europe: A market-potential based approach. Sustainable Cities and Society, 47(June 2018), 101372.

Kristiansen, S., \& Santoso, P. (2006). Surviving decentralisation?. Impacts of regional autonomy on health service provision in Indonesia. Health Policy, 77(3), 247-259. 
Liew, H. P. \& Gardner, S. (2014). Determinants of patient satisfaction with outpatient care in Indonesia: A conjoint analysis approach. Health Policy and Technology, 3(4), 306-313.

Liew, H. P. \& Brooks, T. (2017). A conjoint analysis of inpatient satisfaction ratings in Indonesia. Health Policy and Technology, 6(1), 105-113.

Luo, J., Tian, L., Luo, L., Yi, H., \& Wang, F. (2017). Two-step optimization for spatial accessibility improvement: A case study of health care planning in Rural China. BioMed Research International, 2017.

Munoz, U. H., \& Källestål, C. (2012). Geographical accessibility and spatial coverage modeling of the primary health care network in the Western Province of Rwanda. International journal of health geographics, 11(1), 1-11.

Murad, A. A. (2007). Creating a GIS application for health services at Jeddah city. Computers in Biology and Medicine, 37(6), 879-889.

Nelson, J. A., \& Gingerich, B. S. (2010). Rural health: Access to care and services. Home Health Care Management and Practice, 22(5), 339343.

Páez, A., \& Scott, D. M. (2017). Spatial statistics for urban analysis: A review of techniques with examples Author ( $\mathrm{s}$ ): Antonio Páez and Darren M . Scott Published by: Springer Stable

URL : http://www.jstor.org/stable/41147914 REFERENCES Linked references are available on JSTOR for . 61(1), 53-67.

Putra, W. (2014). Efisiensi pelayanan publik bidang kesehatan pasca pemekaran wilayah Provinsi Kalimantan Barat. Jurnal Penelitian Dan Pengembangan Borneo Akcaya, 01(1), 1-16.

Polo, G., Acosta, C. M., Ferreira, F., \& Dias, R. A. (2015). Location-allocation and accessibility models for improving the spatial planning of public health services. PLoS ONE, 10(3), 1-9. https://doi.org/10.1371/journal.pone.0119190

Roberts, A., Blunt, I., \& Bardsley, M. (2014). Focus On: Distance from home to emergency care. In Quality Watch (Issue February).

Soares, L., Rustiadi, E., \& Mulatsih, S. (2017). Analisis Disparitas dan Interaksi Spasial di Timor-Leste. Journal of Regional and Rural Development Planning, 1(1), 74.

Yin, C., He, Q., Liu, Y., Chen, W., \& Gao, Y. (2018). Inequality of public health and its role in spatial accessibility to medical facilities in China. Applied Geography, 92(February), 5062.
Zeng, D., You, W., Mills, B., Alwang, J., Royster, M., \& Anson-Dwamena, R. (2015). A closer look at the rural-urban health disparities: Insights from four major diseases in the Commonwealth of Virginia. Social Science and Medicine, 140, 62-68.

Zwirowicz-Rutkowska, A. \& Michalik, A. (2016). The Use of Spatial Data Infrastructure in Environmental Management:an Example from the Spatial Planning Practice in Poland. Environmental Management, 58(4), 619-635. 